\title{
Bone and adipose tissue - more and more interdependence
}

\author{
Kość a tkanka tłuszczowa - coraz więcej zależności
}

\author{
Joanna Dytfeld \\ Poznan University of Medical Sciences, Poznan, Poland
}

Key words: osteoporosis, adipokines, osteocalcin.

Stowa kluczowe: osteoporoza, adipokiny, osteokalcyna.

\begin{abstract}
Sum mary
In bone marrow, osteoblasts and adipocytes originate from common progenitor cells - mesenchymal stem cells (MSCs). The further cell differentiation towards one of the two lines, depending on numerous factors, might have an impact on pathologies of bone in further life. Evidence from experimental and clinical studies indicates multiple reciprocal links between skeleton and adipose tissue. Numerous adipocyte products - leptin, adiponectin, etc. directly or indirectly affect bone formation and resorption, which take place constantly. This knowledge verifies our views on obesity, osteoporosis and fragility fractures. We also know that bone remodeling, a process that requires energy, is heavily dependent on insulin; moreover, bone is a source of osteocalcin, a hormone whose role goes far beyond determining the level of bone turnover. The endocrine role of the skeleton becomes a reality.
\end{abstract}

\section{Introduction}

Osteoblasts and adipocytes in bone marrow originate from common precursor cells - the mesenchymal stem cells (MSCs) [1, 2]. Mesenchymal stem cells' differentiation into one of the cell lineages depends on numerous opposing factors resulting in one representation gaining advantage over the other. Recent research findings indicate on the one hand that too many adipocytes compared to osteoblasts within bone marrow may relate to the worsening of bone formation and development of osteoporosis [1]. On the other hand, they show that bone matrix proteins may significantly affect insulin secretion and carbohydrate metabolism. There is increasing evidence for mutual and manifold interdependencies between adipose tissue and bone tissue, which may have

\section{Streszczenie}

Wspólnym prekursorem osteoblastów i adipocytów w szpiku kostnym są mezenchymalne komórki progenitorowe. Wpływ różnorakich czynników warunkuje ich różnicowanie się w kierunku jednej z tych linii, co może mieć znaczenie dla późniejszych zmian patologicznych układu kostnego. Liczne dowody z badań eksperymentalnych i klinicznych przemawiają także za wzajemnymi wielorakimi zależnościami między szkieletem a tkanką tłuszczową. Liczne produkty adipocytów - leptyna, adiponektyna i inne - w sposób pośredni lub bezpośredni wpływają na zachodzące nieustannie procesy kościotworzenia i resorpcji kostnej. Wiedza na ich temat weryfikuje nasze poglądy na temat otyłości, osteoporozy i złamań niskoenergetycznych. Wiadomo także, że remodeling kostny, proces wymagający energii, jest w dużym stopniu zależny od insuliny, a tkanka kostna wytwarza osteokalcynę - hormon, którego rola daleko wykracza poza wyznaczanie ram obrotu kostnego. Coraz więcej faktów przemawia za endokrynną funkcją szkieletu.

vital clinical implications. This article presents an overview of said findings.

\section{Adipocytes and osteoblastogenesis}

Bone marrow comprises two types of precursor cells - hematopoietic and mesenchymal cells. Shortly after birth, hematopoietic cells (red bone marrow) prevail. With time, however, they are gradually substituted by adipose cells (yellow bone marrow). Even though the role of bone marrow adipocytes has not been clearly defined yet, it is a physiological process. Historically, they were treated as a tissue "passively" taking over the niche space not used by hematopoietic cells. This view was revised not long ago. It turned out that adipocytes regulate the bone marrow microenvironment providing energy to

Address for correspondence:

Joanna Dytfeld, MD, PhD, Poznan University of Medical Sciences, Przybyszewskiego 49, 60-355 Poznan, Poland,

e-mail: dytfeld@poczta.onet.pl

Submitted: 14.05 .2014 
the process of remodeling the trabecular bone (bone marrow within said bone contains high quantities of yellow bone marrow) [3]. Bone mass gain in adolescence, which - as indicated above - coexists with bone marrow fat increase with age, speaks in favor of the hypothesis.

Precursor mesenchymal cells were first described by Friedenstein in the late 1960s as "matrix fibroblasts" [4]. They are found in many other tissues apart from bone marrow, such as muscles, cartilage, and adipose tissue, and they are capable of differentiation in more than two directions, i.e. they can differentiate into another mesenchymal lineage, e.g. myocytes or chondrocytes. It is suggested that the "bipotential" precursors of adipocytes/osteoblasts are a special transient form in the differentiation process [5].

There are certain intracellular pathways and transcription factors that determine mesenchymal cell differentiation. Amongst the factors activating osteoblastogenesis are the WNT/ $\beta$-catenin pathway and Msx2, Runx2 and osterix transcription factors' expression, whereas peroxisome proliferator-activated receptors $\gamma$ (PPAR $\gamma$ ) and members of the C/EBP family (CCAAT-enhancer binding protein) promote adipogenesis [6-8]. The PPAR $\gamma$ nuclear hormone receptor subfamily is de facto a group of transcription factors activated by ligands that also includes steroid hormone, vitamin D and retinoid acid receptors. Two isoforms of the protein exist: PPAR 1 1, expressed in numerous cell types, and PPAR $\gamma 2$ with an additional 28-amino acid radical, the expression of which is limited to adipocytes and bone marrow stromal cells. PPAR $\gamma$ present in the cell nucleus is activated by the ligand, then conformational changes occur and a heterodimer is formed with the retinoid $X$ receptor (RXR)- $\alpha$. Subsequently, the above structure is combined with PPREs (PPAR $\gamma$ response elements) in the promoter region of target genes and modulates their expression. PPARys are necessary for the regulation of energy conservation. A diet abundant in fats enhances their activity and lipogenesis; a diet poor in fats results in the mobilization of fat reserves in the adipose tissue and in lipolysis. Overfeeding causes continuous PPAR $\gamma$ activation, excessive accumulation of fats, and obesity [9].

The receptors are activated at preadipocyte differentiation into adipocytes; they are present in the white and brown adipose tissue. Numerous experiments demonstrate that they are the superior regulator of adipogenesis. Studies with the involvement of embryonic cells devoid of PPAR 2 revealed no differentiation into adipose tissue [10]. Increased PPAR 2 expression in bone marrow-derived progenitor cells promotes excessive proliferation of adipose tissue therein and osteoblastogenesis suppression, probably due to decreased activity of the osteoblast-specific Runx2 transcription factor [11].
Therefore, PPAR $\gamma 2$ overexpression is ascribed a negative impact on the process of bone formation as it decreases the number and function of osteoblasts, which ultimately may lead to the loss of bone mass and osteoporosis.

These observations were partially confirmed at the time of introducing PPAR $\gamma$ receptor agonists (thiazolidinediones - TZD) into the treatment of type 2 diabetes. Despite the positive antihyperglycemic activity (increasing insulin sensitivity), the drugs had an adverse effect on the bone. Initial observations appeared after the publication of the ADOPT trial (A Diabetes Outcome Progression Trial), which demonstrated an increased fracture rate during rosiglitazone therapy when compared to metformin and glyburide treatment $(\mathrm{HR}=1.8$ in comparison with metformin, 2.1 in comparison with glyburide) [12]. The metaanalysis of Loke et al. of 12 studies (10 placebo-controlled randomized studies and 2 observation studies - more than 77,000 patients in total) confirmed said observations as it proved that long-term TZD use doubled the risk of fractures in type 2 diabetes females [13]. No such interdependency was noted in males.

\section{Metabolic activity of adipose tissue and osteogenesis}

Studies conducted in the last several years indicate that bone marrow adipocytes have the characteristic features of subcutaneous and visceral fat $[1,14]$. They are metabolically active as they secrete multiple biologically active substances that affect osteoblastogenesis.

Compounds which have an unquestionable influence on osteogenesis are estrogens. Their osteogenic activity, or rather a lack thereof, is most frequently referred to in the context of postmenopausal osteoporosis. The main estrogen in the period is estrone originating from peripheral aromatization of androstenedione in adipose tissue. The conversion appears higher in obese women due to a higher fatty tissue mass. Adipose tissue content in bone marrow also increases after menopause to the disadvantage of osteogenic cells.

Nowadays, the issue of osteoclastic activity comes up in the context of aromatase inhibitors therapy in breast cancer. Still, the effect of estrogens on the bone is observed at a much earlier stage in the life of women, whereas their deficiency is most significant during lactation. It is when the osteoclast life extends, the parathormone related protein (PTHrP) concentration increases and bone calcium is mobilized. However, the adverse effect of breastfeeding on bone mineral density (BMD) seems temporary and reversible [15].

The most abundant adipocytokine in adipose tissue is adiponectin, known for its anti-inflammatory proper- 
ties and positive effect on insulin sensitivity [16]. Low concentrations of adiponectin in blood serum have been proven to coexist with numerous disorders, such as diabetes mellitus or clinically overt atherosclerosis including heart infarct $[17,18]$. Its serum levels inversely correlate with adipose tissue contents - in obese patients we can observe hypoadiponectinemia [19]. It has been established that adiponectin and its receptors (AdipoR1 and AdipoR2) are expressed in osteoblasts and osteoclasts [20, 21]. However, its impact on bone tissue metabolism is manifold. In vitro studies revealed that the protein promotes precursor cells' differentiation into preosteoblasts and that at the following stage it stimulates osteoblast proliferation, maturation and mineralization [22]. Another manner in which the described adipocytokine affects the bone is through its impact on the differentiation of osteoclasts. Zhang et al. demonstrated that the administration of recombinant adiponectin promoted osteoclast differentiation indirectly by inhibiting the expression of osteoprotegerin (OPG) in osteoblasts [23]. Hu et al. [24] observed an inverse, inhibiting effect on osteoclastogenesis, and it was a direct effect on bone tissues. It is postulated that the observed differences may result from the paths of adiponectin's activity: autocrine/paracrine signaling and endocrine signaling.

Nevertheless, experimental studies' results stand in contradiction to the observation studies, with the majority of the papers revealing a negative correlation between serum adiponectin level and BMD [25-27]. The metaanalysis of Biver et al. involving 59 studies demonstrated that adiponectin is the strongest adipocytokine negatively associated with BMD regardless of the gender, age and adipose tissue content [28]. High levels of serum adiponectin in men have become a good predictor of vertebral fractures [29]. There are several potential causes of the above discrepancies between the experimental and clinical trials. Firstly, clinical evaluation involves the level of blood serum adiponectin, i.e. the product of peripheral adipocytes, whereas the concentration of bone marrow plasma adiponectin may actually be higher, as demonstrated by one of the authors [30]. Secondly, the interdependencies between adiponectin and BMD referred to in the article were evaluated in patients diagnosed with osteoporosis. Many authors assume that higher levels of adiponectin in those patients is a defensive reaction against osteopenia observed in a positive feedback mechanism. Thirdly, the molecular forms of adiponectin may also have a stake in the process since adiponectin may take the form of trimers of low molecular weight (LMW), hexamers of medium molecular weight (MMW) and oligomers of high molecular weight (HMW). It is thought that the greatest intensification of insulin sensitivity is achieved by the HMW form consequential to
AMP kinase stimulation [31]. It is debatable, though, which form affects the osteoblast and whether it occurs in the specified metabolic pathway.

The first known adipocytokine, leptin, the product of the ob gene, is a substance that has numerous biological functions. It is produced primarily in the white adipose tissue, proportionally to its content, as well as in brown adipose tissue, ovaries, liver, and endothelial cells [32]. Leptin's activity consists in hypothalamic action leading to inhibition of the sensation of hunger, inhibition of food intake and increase in thermogenesis. Unlike adiponectin, its serum levels in obese persons are high and decrease with body weight loss [33]. In addition to obesity, experimental models of mice void of the leptin gene (ob/ob mice) or its receptors ( $d b / d b$ mice) demonstrate decreased cortical bone density, increased trabecular bone density [34, 35], and increased adipocyte count in bone marrow. It is suggestive of a varied effect of leptin on the cortical and trabecular bone. Findings regarding the mechanisms of the described activity are contradictory. Some authors suggest that leptin produced by bone marrow adipocytes affects osteoblasts directly because they are equipped with leptin receptors and that it is a beneficial effect. It is said to promote stem cell differentiation into osteoblasts, inhibit adipogenesis, and increase OPG levels. Leptin's effect on the cortical bone is probably an indirect one involving neurohormones and the sympathetic system [36]. Elefteriou et al. showed that intraventricular leptin administration in rat leads to release of noradrenaline, which further binds to the $\beta 2$-adrenergic receptor in the hypothalamus, consequently leading to the expression of receptor activator of nuclear factor $\kappa \mathrm{B}$ (RANKL) and promoting osteoclast activation [37]. Thus, it demonstrates osteoclastic activity. Many researchers are inclined to agree that both arms of the bone restructuring process, osteogenesis and resorption, are negatively controlled by leptin.

Clinical observations regarding the correlation between BMD and leptin concentration in humans provide unclear results. Most papers indicate that there is no correlation between leptin levels and $\operatorname{BMD}[38,39]$; there are few demonstrating a positive correlation both in postmenopausal women and men [40, 41].

\section{Bone and energy balance}

Until recently, the skeleton has been considered an endocrinologically passive tissue that is the target for, amongst others, parathormone and steroid hormones. The reason why we might believe quite differently is one protein secreted by mature osteoblasts, i.e. osteocalcin (OC). It consist of 46-50 amino acids and undergoes a posttranslational carboxylation in three glutamic 
acid residues. The residues demonstrate high affinity to hydroxyapatite of the bone, hence the presence of OC within bone matrix [42]. Osteocalcin is then released to blood during bone resorption processes with the participation of osteoclasts. The levels of blood serum OC are used to assess the bone turnover rate and to monitor osteoporosis treatment. There are more and more data indicating that the active form of the protein is the decarboxylated form (ucOC) [43]. However, the existence of decarboxylases which were to take part in the process has not been proved yet. This role seems to be played by the product of the Esp gene (embryonic stem cell) OST-PTP (osteotesticular protein tyrosine phosphatase). It is a type of tyrosine phosphatase expressed in osteoblasts and Sertoli cells [44], whose exact mechanism of action remains unknown.

Osteocalcin is one of the few osteoblast-specific proteins. What is more, it has some features of a hormone: secreted in a single place of the body, it affects the functioning of remote organs. Karsenty's research team proved at first that mice deficient in osteocalcin $\left(\mathrm{OCn}^{-} /\right)$present hyperglycemia, hypoinsulinemia, decreased expression of target genes for insulin activity in the liver (Foxa2, Mcad, Nrft, etc.) and markers of insulin resistance [45]. They are characterized by a low mass of both pancreatic islets and $\beta$ cells, which results in insufficient insulin secretion, and an increase in visceral fat and triglyceride levels. However, they do not represent a pathological phenotype within the bone. Experimental research showed that administration of recombinant (decarboxylated) OC to mice increases insulin concentration, improves peripheral glucose utilization, intensifies cell proliferation in $\beta$ cell cultures, and stimulates insulin gene expression [46].

Further studies led to the conclusion that the factor significantly contributing to the escalation of osteocalcin expression in osteoblasts and the secretion of its active form from the bone is indeed insulin (it occurs in the presence of insulin receptor found on the surface of osteoblasts) [47]. Thus, what we encounter here is a positive feedback loop: a signal sent by the pancreas via an osteoblast promotes osteocalcin secretion, which in turn stimulates beta cells to produce insulin. One may presume that the process is to compensate energy expenditure related to osteogenesis, and the term "bone-pancreas axis" has been coined as a result [14, 48]. The bond of negative regulation that is necessary in every biological process turns out to be leptin. As a central stimulant of sympathetic nervous system tension (activation of $\beta 2$ receptors), it inhibits both secretion and activation of osteocalcin [43].

Authors of multiple papers have proved that the concentration of the total as well as decarboxylated osteoc- alcin negatively correlates with the fasting glucose level, adipose tissue content, body mass index (BMI), insulin resistance markers, and glycated hemoglobin $\left(\mathrm{HbA}_{1 c}\right)$ in healthy individuals as well as diabetic patients [49-51]. Diabetic patients present lower OC levels when compared to unaffected individuals [52]. Diaz-Lopez et al. demonstrated that low levels of carboxylated and decarboxylated osteocalcin in individuals with an elevated risk of cardiovascular diseases were an independent factor increasing the probability of developing type 2 diabetes [53].

Another target organ for $\mathrm{OC}$ is adipose tissue, in which OC positively regulates adiponectin expression, which in turn stimulates osteogenesis through receptors located in osteoblasts [54]. What is more, it has been evidenced that by interaction with $\mathrm{G}$ protein-related receptor (Gprc6a), decarboxylated osteocalcin stimulates testosterone synthesis in Leydig cells in animals and humans; hence male gonads are probably an effector tool, too [55].

The involvement of osteocalcin in carbohydrate homeostasis regulation gives rise to an important question about the potential use of its increased levels in hyperglycemia treatment. The promising experimental studies mentioned above demonstrated that subcutaneous injections of recombinant osteocalcin may potentially be applied in the treatment of diabetes [46]. Another aspect of this issue concerns the low OC levels consequential to osteoporotic treatment with bisphosphonates (a decrease of > 15\% compared with baseline values is an indicator of antifracture efficacy) [56]. Osteocalcin concentration is also lowered during hormone replacement therapy [57]. Vitamin K antagonist therapy leads to osteocalcin $\gamma$-carboxylation impairment, too, distorting the formation of its active form [58]. Thus, may such treatment develop a risk of worsening the carbohydrate balance parameters or promote diabetes? The question remains open, and so do other questions, such as whether slimming (or obesity) may lead to alterations in the concentration of circulating $\mathrm{OC}$ or whether it can have a long-term effect on skeleton condition. Meanwhile, numerous findings regarding biological activity of osteocalcin require confirmation in clinical trials.

It seems that the fact of common origin of osteoblast and adipocyte may be highly relevant to the further "life" of the cells; as one can see, they affect their functions mutually and multidirectionally. Abundant evidence lets us treat the bone as an endocrine organ that actively participates in the regulation of energy balance of the body. Newly learnt interdependencies between the products of the bone tissue, adipocytes and pancreas instigate new questions regarding both novel therapeutic indications and the safety of the ones used to date. 
The author declares no conflict of interest.

\section{References}

1. Gimble JM, Zvonic S, Floyd ZE, et al. Playing with bone and fat. J Cell Biochem 2006; 98: 251-266.

2. Bianco P, Riminucci M, Gronthos S, Robey PG. Bone marrow stromal stem cells: nature, biology, and potential applications. Stem Cells 2001; 19: 180-192.

3. Gimble JM, Robinson CE, Wu X, Kelly KA. The function of adipocytes in the bone marrow stroma: an update. Bone 1996; 19: 421-428.

4. Friedenstein AJ, Piatetzky-Shapiro II, Petrakova KV. Osteogenesis in transplants of bone marrow cells. J Embryol Exp Morphol 1966; 16: 381-390.

5. Hasegawa T, Oizumi K, Yoshiko Y, et al. The PPARgamma-selective ligand BRL-49653 differentially regulates the fate choices of rat calvaria versus rat bone marrow stromal cell populations. BMC Dev Biol 2008; 8: 71.

6. Yoon WJ, Cho YD, Kim WJ, et al. Pin1-mediated conformational change and subnuclear focal accumulation of Runx2 is crucial for FGF2-induced osteoblast differentiation. J Biol Chem 2014; 289: 8828-8838.

7. Sinha KM, Yasuda H, Zhou X, deCrombrugghe B. Osterix and NO66 histone demethylase control the chromatin architecture of Osterix target genes during osteoblast differentiation. J Bone Miner Res 2014; 29: 855-865.

8. Morsczeck C. Gene expression of runx2, Osterix, c-fos, DLX-3, DLX-5, and MSX-2 in dental follicle cells during osteogenic differentiation in vitro. Calcif Tissue Int 2006; 78: 98-102.

9. Lecka-Czernik B. PPARs in bone: the role in bone cell differentiation and regulation of energy metabolism. Curr Osteoporos Rep 2010; 8: 84-90.

10. Akune T, Ohba S, Kamekura S, et al. PPARgamma insufficiency enhances osteogenesis through osteoblast formation from bone marrow progenitors. J Clin Invest 2004; 113: 846-855.

11. Liu LF, Shen WJ, Zhang ZH, et al. Adipocytes decrease Runx2 expression in osteoblastic cells: roles of PPARgamma and adiponectin. J Cell Physiol 2010; 225: 837-845.

12. Kahn SE, Zinman B, Lachin JM, et al. Rosiglitazone-associated fractures in type 2 diabetes: an Analysis from A Diabetes Outcome Progression Trial (ADOPT). Diabetes Care 2008; 31: 845-851.

13. Loke YK, Singh S, Furberg CD. Long-term use of thiazolidinediones and fractures in type 2 diabetes: a meta-analysis. CMA 2009; 180: 32-39.

14. Sadie-Van Gijsen H, Crowther NJ, Hough FS, Ferris WF. The interrelationship between bone and fat: from cellular see-saw to endocrine reciprocity. Cell Mol Life Sci 2013; 70: 2331-2349.

15. Dytfeld J, Horst-Sikorska W. Pregnancy associated osteoporosis - a case report. Ginekol Pol 2012; 83: 377-379.

16. Galic S, Oakhill JS, Steinberg GR. Adipose tissue as an endocrine organ. Mol Cell Endocrinol 2010; 316: 129-139.

17. Pischon T, Girman CJ, Hotamisligil GS, et al. Plasma adiponectin levels and risk of myocardial infarction in men. JAMA 2004; 291: 1730-1737.

18. Spranger J, Kroke A, Möhlig M, et al. Adiponectin and protection against type 2 diabetes mellitus. Lancet 2003; 361: 226-228.
19. Baratta R, Amato S, Degano C, et al. Adiponectin relationship with lipid metabolism is independent of body fat mass: evidence from both cross-sectional and intervention studies. J Clin Endocrinol Metab 2004; 89: 2665-2671.

20. Berner HS, Lyngstadaas SP, Spahr A, et al. Adiponectin and its receptors are expressed in bone-forming cells. Bone 2004; 35: 842-849.

21. Pacheco-Pantoja EL, Waring VJ, Wilson PJ, et al. Adiponectin receptors are present in RANK-L-induced multinucleated osteoclast-like cells. J Recept Signal Transduct Res 2013; 33: 291-297.

22. Shinoda Y, Yamaguchi M, Ogata N, et al. Regulation of bone formation by adiponectin through autocrine/paracrine and endocrine pathways. J Cell Biochem 2006; 99: 196-208.

23. Zhang Y, Zhou P, Kimondo JW. Adiponectin and osteocalcin: relation to insulin sensitivity. Biochem Cell Biol 2012; 90: 613620.

24. Hu E, Liang P, Spiegelman BM. AdipoQ is a novel adipose-specific gene dysregulated in obesity. J Biol Chem 1996; 271 : 10697-10703.

25. Richards JB, Valdes AM, Burling K, et al. Serum adiponectin and bone mineral density in women. J Clin Endocrinol Metab 2007; 92: 1517-1523.

26. Jürimäe J, Jürimäe T. Plasma adiponectin concentration in healthy pre- and postmenopausal women: relationship with body composition, bone mineral, and metabolic variables. Am J Phys 2007; 293: E42-E47.

27. Basurto L, Galván R, Cordova N, et al. Adiponectin is associated with low bone mineral density in elderly men. Eur J Endocrinol 2009; 160: 289-293.

28. Biver E, Salliot C, Combescure C, et al. Influence of adipokines and ghrelin on bone mineral density and fracture risk: a systematic review and meta-analysis. J Clin Endocrinol Metab 2011; 96: 2703-2713.

29. Johansson H, Odén A, Lerner UH, et al. High serum adiponectin predicts incident fractures in elderly men: Osteoporotic fractures in men (MrOS) Sweden. J Bone Miner Res 2012; 27: 1390-1396.

30. Berner HS, Lyngstadaas SP, Spahr A, et al. Adiponectin and its receptors are expressed in bone-forming cells. Bone 2004; 35: 842-849.

31. Pajvani UB, Du X, Combs TP, et al. Structure-function studies of the adipocyte-secreted hormone Acrp3/adiponectin. Implications for metabolic regulation and bioactivity. J Biol Chem 2003; 278: 9073-9085.

32. Considine RV. Human leptin: an adipocyte hormone with weight regulatory and endocrine functions. Semin Vasc Med 2005; 5: 15-24.

33. Miller LE, Volpe JJ, Coleman-Kelly MD, et al. Anthropometric and leptin changes in women following different dietary approaches to weight loss. Obesity 2009; 17: 199-201.

34. Williams GA, Callon KE, Watson M, et al. Skeletal phenotype of the leptin receptor-deficient $\mathrm{db} / \mathrm{db}$ mouse. J Bone Miner Res 2011; 26: 1698-1709.

35. Hamrick MW, Della-Fera MA, Choi YH, et al. Leptin treatment induces loss of bone marrow adipocytes and increases bone formation in leptin-deficient ob/ob mice. J Bone Miner Res 2005; 20: 994-1001. 
36. Reid IR. Fat and bone. Arch Biochem Biophys 2010; 503: 20-27.

37. Elefteriou F, Ahn JD, Takeda S, et al. Leptin regulation of bone resorption by the sympathetic nervous system and CART. Nature 2005; 434: 514-520.

38. Koroglu BK, Kiris F, Ersoy IH, et al. Relation of leptin, adiponectin and insulin resistance to bone mineral density in type 2 diabetic postmenopausal women. Endokrynol Pol 2011; 62 429-435.

39. Wu N, Wang QP, Li H, et al. Relationships between serum adiponectin, leptin concentrations and bone mineral density, and bone biochemical markers in Chinese women. Clin Chim Acta 2010; 411: 771-775.

40. Jürimäe J, Jürimäe T, Leppik A, Kums T. The influence of ghrelin, adiponectin, and leptin on bone mineral density in healthy postmenopausal women. J Bone Miner Metab 2008; 26: 618-623.

41. Vasilkova O, Mokhort T, Sharshakova T, et al. Leptin is an independent determinant of bone mineral density in men with type 2 diabetes mellitus. Acta Diabetol 2011; 48: 291-295.

42. Hauschka PV, Lian JB, Cole DE, Gundberg CM. Osteocalcin and matrix Gla protein: vitamin K-dependent proteins in bone. Physiol Rev 1989; 69: 990-1047.

43. Ducy P. The role of osteocalcin in the endocrine cross-talk between bone remodelling and energy metabolism. Diabetologia 2011; 54: 1291-1297.

44. Mauro LJ, Olmsted EA, Skrobacz BM, et al. Identification of a hormonally regulated protein tyrosine phosphatase associated with bone and testicular differentiation. J Biol Chem 1994; 269: 30659-30667.

45. Lee NK, Sowa $H$, Hinoi E, et al. Endocrine regulation of energy metabolism by the skeleton. Cell 2007; 130: 456-469.

46. Ferron M, Hinoi E, Karsenty G, Ducy P. Osteocalcin differentially regulates beta cell and adipocyte gene expression and affects the development of metabolic diseases in wild-type mice. Proc Natl Acad Sci U S A 2008; 105: 5266-5270.

47. Yadav VK, Oury F, Suda N, et al. A serotonin-dependent mechanism explains the leptin regulation of bone mass, appetite, and energy expenditure. Cell 2009; 138: 976-989.

48. Pi M, Quarles LD. Novel bone endocrine networks integrating mineral and energy metabolism. Curr Osteoporos Rep 2013, 11: 391-399.

49. Kanazawa I, Yamaguchi T, Yamamoto M, et al. Serum osteocalcin level is associated with glucose metabolism and atherosclerosis parameters in type 2 diabetes mellitus. J Clin Endocrinol Metab 2009; 94: 45-49.

50. Pittas AG, Harris SS, Eliades M, et al. Association between serum osteocalcin and markers of metabolic phenotype. J Clin Endocrinol Metab 2009; 94: 827-832.

51. Motyl KJ, McCabe LR, Schwartz AV. Bone and glucose metabolism: a two-way street. Arch Biochem Biophys 2010; 503 2-10.

52. Lucey AJ, Paschos GK, Thorsdottir I, et al. Young overweight and obese women with lower circulating osteocalcin concentrations exhibit higher insulin resistance and concentrations of C-reactive protein. Nutr Res 2013; 33: 67-75.

53. Díaz-López A, Bulló $M$, Juanola-Falgarona $M$, et al. Reduced serum concentrations of carboxylated and undercarboxylated osteocalcin are associated with risk of developing type 2 diabetes mellitus in a high cardiovascular risk population: a nested case-control study. J Clin Endocrinol Metab 2013; 98: 4524-4531.

54. Ng KW. Regulation of glucose metabolism and the skeleton. Clin Endocrinol 2011; 75: 147-155.

55. Karsenty G, Oury F. Regulation of male fertility by the bone-derived hormone osteocalcin. Mol Cell Endocrinol 2014; 382: 521-526.

56. Goncerz G. Polskie zalecenia postępowania diagnostycznego i leczniczego w osteoporozie - podsumowanie aktualizacji 2013. Reumatologia 2013; 1: 33-46.

57. Dane C, Dane B, Cetin A, Erginbas M. Comparison of the effects of raloxifene and low-dose hormone replacement therapy on bone mineral density and bone turnover in the treatment of postmenopausal osteoporosis. Gynecol Endocrinol 2007; 23: 398-403.

58. Ferron M, Wei J, Yoshizawa T, et al. Insulin signaling in osteoblasts integrates bone remodeling and energy metabolism. Cell 2010; 142: 296-308. 